\title{
Risk Management of Incidental Gallbladder Cancer in Cholecystectomy Materials
}

\author{
Kolesistektomi Materyallerinde Insidental Safra Kesesi \\ Kanserinin Risk Yönetimi
}

Fahriye Kilinc, Ugur Gulper,

Pembe Oltulu, Siddika Findik, Hasan Esen, Salim Gungor,

Necmettin Erbakan University Meram Faculty of Medicine, Medical Pathology Department, Konya, Turkey

Geliş Tarihi/Received: 1 May 2018
Kabul Tarihi/Accepted: 15 December 2018

\begin{abstract}
Öz
Amaç: Safra kesesi kanseri yaygın olmayan fakat agresif bir tümördür. Prognozu kötüdür ve olguların çoğu benign hastalıklar nedeniyle yapılan kolesistektomilerin histopatolojik incelenmesinde insidental olarak tespit edilir. Laparaskopik kolesistektomi dönemiyle erken evrede tespit edilen olguların sayısı artmaktadır. Bu çalışmada, bölümümüze gönderilen kolesistektomi materyallerinde kanserle karşılaşma oranını ve kanser dışı tanıların dağılımını literatür bulguları eşliğinde değerlendirmeyi amaçladık.

Gereçler ve Yöntem: 2016-2017 yıllarında patoloji bölümüne gönderilen ve rutin olarak incelenen kolesistektomi materyallerinin sonuçları tanı grupları oluşturularak retrospektif olarak değerlendirildi. Hastaların klinik ön tanıları, demografik bilgileri (yaş, cinsiyet) ve patoloji raporları gözden geçirildi. Bulgular: Toplam 1000 kolesistektomi materyalini çalışmaya dahil ettik. Malignite bulunan 7 hastanın 2'sinde insidental olarak tanı konulmuştu ve kolelitiazis ön tanısıyla laparoskopik kolesistektomi yapılmıştı, bir hastada primer odak safra kesesiydi, diğeri kolon adenokarsinom infiltrasyonu ile uyumluydu. Kalan 5 hastada preoperatif ve / veya postoperatif malignite tespit edilmişti. Diğer olguların büyük kısmında (>\%90) kronik veya kronik aktif kolesistit, düşük oranda akut kolesistit, 2 'sinde $(\% 0,2)$ gastrik heterotopi, 1 'inde $(\% 0,1)$ tubuler adenom, 1 'inde $(\% 0,1)$ tubulovillöz adenom, 4 'ünde $(\% 0,4)$ adenomyom / adenomyomatozis, 6 'sında $(\% 0,6)$ polip ve 5 'inde $(\% 0,5)$ displazi (Bilier intraepitelyal neoplazi, BillN) mevcuttu.

Sonuç: Geç evrelere ilerleyene kadar sessiz kalan kötü prognozlu bir tümör için \% $0,1^{\prime}$ lik insidental oranın düşük olmadığını düşünmekteyiz. Bu nedenle makroskopik olarak belirgin lezyon olmasa bile histopatolojik değerlendirme için özellikle fundus, boyun ve yan duvarlar örneklenmelidir.
\end{abstract}

Anahtar Kelimeler: Kolesistektomi, histopatoloji, safra kesesi kanseri, insidental

\section{Abstract}

Address correspondence to: Fahriye Kilinc,
Necmettin Erbakan University Meram Faculty of Medicine, Medical Pathology Department Meram, Konya, Turkey

e-mail: drfahriyek@gmail.com

\section{ORCID}

Fahriye Kilinc

https://orcid.org/0000-0002-1202-8735

Aim: Gallbladder cancer is an uncommon, but aggressive tumor. Its prognosis is poor and the most cases are incidentally detected in histopathological examinations of cholecystectomies due to benign diseases. With the era of laparoscopic cholecystectomy, the number of cases detected in early stage is increasing. In this study, we aimed to evaluate the rate of cancer encountered and the distribution of non-cancer diagnoses in cholecystectomy materials sent to our department, together with the literature findings. Materials and Methods: The results of the cholecystectomy materials sent to the pathology laboratory and examined routinely in 2016-2017 were retrospectively evaluated by forming diagnostic groups. Clinical preliminary diagnoses, demographic informations (age, sex), and pathology reports of the patients were reviewed

Results: We included a total of 1000 cholecystectomy materials into the study. Two of the 7 patients who presented with malignancy were incidentally diagnosed and underwent laparoscopic cholecystectomy with the preliminary diagnosis of cholelithiasis, with the primary focus was gallbladder in one patient, and the other was compatible with colonic adenocarcinoma infiltration. Preoperative and / or perioperative malignancy was detected in the remaining 5 patients. A large proportion (>90\%) of the other cases had chronic or chronic active cholecystitis and low rate of acute cholecystitis included gastric heterotopia found in $2(0.2 \%)$, tubular adenoma in $1(0.1 \%)$, tubulovillous adenoma in $1(0.1 \%)$, adenomyoma / adenomyomatosis in $4(0.4 \%)$, polyp in $6(0.6 \%)$ and dysplasia (Biliary intraepithelial neoplasia, BillN) in $5(0.5 \%)$ patients.

Conclusion: We think that the incidental rate of $0.1 \%$ is not low for a poorly prognostic tumor that remains silent until progressing to late stages. Especially fundus, neck and lateral walls should be sampled for histopathological evaluation, even if there is no macroscopically evident lesion.

Key words: Cholecystectomy, histopathology, gallbladder cancer, incidental

\section{INTRODUCTION}

Gallbladder cancer is the first of the biliary system cancers, the fifth of the gastrointestinal system cancers (1). Among all cancers in the United States, its percentage is $0.17 \%$ in males and $0.49 \%$ in females (2). It is usually asymptomatic in the early stages, when symptomatic, it occurs with findings similar to benign cases such as chronic cholecystitis (1). The risk of cancer encountered in cholecystectomy materials that were examined with a preliminary diagnosis of a benign disease was reported as $0.19-3.3 \%$ in the literature. Gallbladder carcinoma which is detected
Cite this article as: Kilinc F, Gulper U, Oltulu P, Findik S, Esen H, Gungor S. Risk Management of Incidental Gallbladder Cancer in Cholecystectomy Materials. Selcuk Med J 2019;35(1): 9-14
Disclosure: None of the authors has a financial interest in any of the products, devices, or drugs mentioned in this article. The research was not sponsored by an outside organization. All authors have agreed to allow full access to the primary data and to allow the journal to review the data if requested. 
by histopathologic examination of the gallbladder for the first time, and not noticed during or before the operation, is defined as incidental gallbladder carcinoma. Most patients with gallbladder cancer (estimated at $60-80 \%$ ) are diagnosed incidentally after cholecystectomy with a preliminary diagnosis of a benign disease (3).

Gallbladder cancer has very good prognosis when detected in an early stage (1). This malignancy remains silent in the initial period and is asymptomatic until the development of noncurative and aggressive disease in the advanced stage (4). The significance of early diagnosis of this poorly prognostic tumor was emphasized in various studies, and some researcher have proposed that the histopathological evaluation of cholecystectomy materials is selective for cases of benign conditions considered clinically and radiologically (1).

In this work, we purposed to evaluate the results of histopathological examinations of cholecystectomy materials sent to our department and to detect the incidence of incidental gallbladder cancer, so evaluating the risk of gallbladder cancer and discussing what we should do about cancer detection.

\section{MATERIALS AND METHODS}

The results of the cholecystectomy materials sent to the pathology laboratory and examined routinely in 2016-2017 were retrospectively evaluated by forming diagnostic groups. The main diagnostic groups were recorded as chronic cholecystitis, chronic active cholecystitis, acute cholecystitis, cholelithiasis, carcinoma, adenoma, and adenomyoma, dysplasia. Clinical preliminary diagnoses, demographic informations (age, sex), and pathology reports of the patients were reviewed.

\section{RESULTS}

We included a total of 1000 cholecystectomy materials into the study. Of all patients, 651 were female, and 349 were male. The age range was 21-85 (median age 64, mean age 35.50). Two of the 7 patients who presented with malignancy were incidentally diagnosed and underwent laparoscopic cholecystectomy with the preliminary diagnosis of cholelithiasis, the primary focus was gallbladder in one patient, and the other was compatible with colonic adenocarcinoma infiltration. Pre-and / or perioperative malignancy was detected in the remaining 5 patients. Incidental patient with primary carcinoma was 62 years old and female patient, the tumor was localized at the fundus in $4,5 \mathrm{~cm}$ in diameter and an ulcerated hard area, and gall stones were present. Tumor showed invasion to perimuscular tissue and pathological stage was evaluated as T2a. Chronic or chronic active cholecystitis were found in a large proportion of the other cases (more than 90\%), and low proportion acute cholecystitis included $2(0.2 \%)$ gastric heterotopia, $1(0.1 \%)$ tubular adenoma, 1 $(0.1 \%)$ tubulovillous adenoma, $4(0.4 \%)$ adenomyoma I adenomyomatosis, 6 (0.6\%) polyp and $5(0.5 \%)$ dysplasia cases (Table 1 and Figure 1).

\section{DISCUSSION}

Carcinomas are the most common tumors of the gallbladder and extrahepatic biliary tract, and very small part of adenomas, carcinoids and stromal tumors (2).

It has been reported that the incidence of gallbladder cancer is very high in India, Chile and some regions of Japan, while in other countries there is a lower incidence (5).

Gallbladder cancer is encountered 2-3 times more

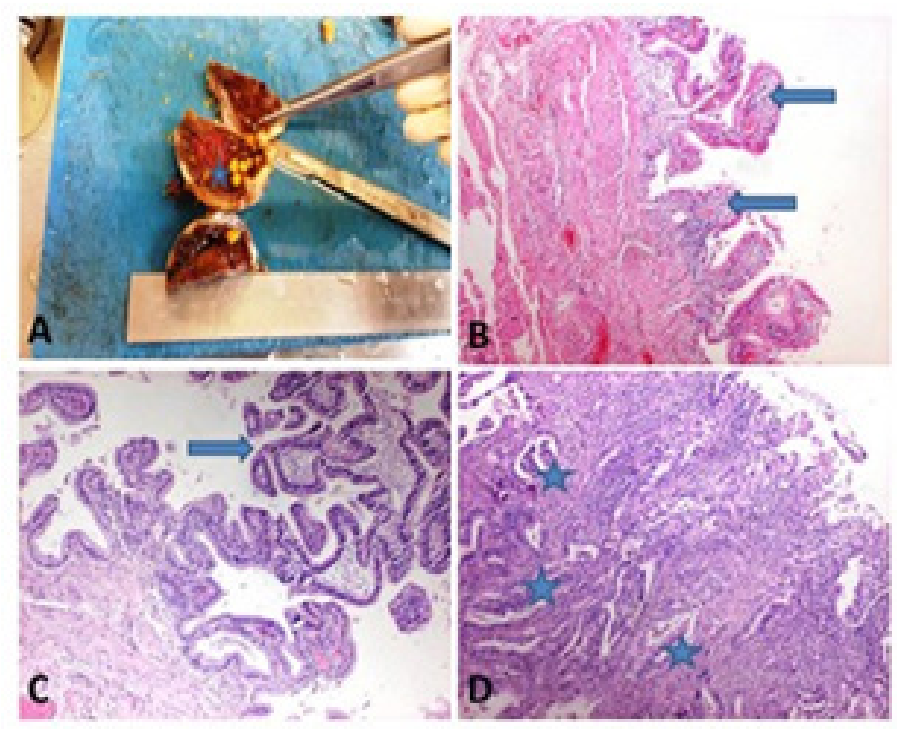

Figure 1. A. Macroscopic view of a cholecystectomy material. Luminal gall stones are present (star). B. Microscopically mononuclear inflammatory cells are observed at the lamina propria (arrows). This is a chronic cholecystitis image (hematoxylin and eosin, 40X). C. Polyp with foamy histiocytes in the stroma is seen on the upper right (arrow). There is a gall bladder wall in the lower left (hematoxylin and eosin, 40X). D. Microscopic appearance of incidentally detected primary gallbladder cancer. Irregular glandular structures (stars) infiltrate the wall (hematoxylin and eosin, 40X). 
Table 1. Diagnoses and rates of cholecystectomy cases.

\begin{tabular}{llll}
\hline Patient No & Age & Sex & Histopathological Diagnosis \\
\hline 1 & 62 & Female & Primary Adenocarcinoma \\
2 & 68 & Male & Secondary infiltration of Adenocarcinoma \\
3 & 84 & Male & Secondary infiltration of Adenocarcinoma \\
4 & 56 & Female & Secondary infiltration of Adenocarcinoma \\
5 & 47 & Male & Secondary infiltration of Adenocarcinoma \\
6 & 85 & Female & Secondary infiltration of Adenocarcinoma \\
7 & 72 & Female & Secondary infiltration of Adenocarcinoma \\
8 & 77 & Female & Gastric Heterotopia \\
9 & 50 & Female & Gastric Heterotopia \\
10 & 64 & Female & Tubular Adenoma \\
11 & 53 & Female & Tubulovillous adenoma \\
12 & 57 & Male & Adenomyomatosis \\
13 & 68 & Male & Adenomyoma \\
14 & 52 & Female & Adenomyomatosis \\
15 & 64 & Female & Adenomyoma \\
16 & 42 & Male & Polyp \\
17 & 39 & Male & Polyp \\
18 & 27 & Male & Polyp \\
19 & 33 & Female & Polyp \\
20 & 22 & Female & Polyp \\
21 & 70 & Male & Polyp \\
22 & 53 & Male & Dysplasia (BillN-I) \\
23 & 55 & Female & Dysplasia (BillN-I) \\
24 & 50 & Female & Dysplasia (BillN-I) \\
25 & 23 & Female & Dysplasia (BillN-I) \\
26 & 64 & Female & Dysplasia (BillN-I) \\
\hline
\end{tabular}

frequently in males than females, peaking in the seventh decade (6). Our primary carcinoma case was a 62-year-old woman.

The clinical findings of gallbladder cancer are similar to those of benign gallstone disease; therefore, preoperative diagnosis is difficult (3). These are nonspecific findings, such as right hypochondrium pain, appetite and weight loss and nausea and vomiting, as well as non- distinguished findings from cholelithiasis (5). Symptoms of cholelithiasis vary from acute diseases such as biliary colic, acute cholecystitis, empyema and gangrenous perforation to subacute findings such as biliary dyspepsia (7). However, jaundice, hepatomegaly and abdominal mass may be suggestive of gallbladder cancer (5). Gallstones are found in 54-97\% of cases with gallbladder cancer (6). Gallbladder cancer is more common in cases with gallstones than in without. From another perspective, the risk of gallbladder cancer is low in cases with stones, and gallbladder cancer develops in less than $3 \%$ of individuals with cholelithiasis (4). In our study, we think that our case with primary gallbladder carcinoma could not be detected preoperatively because it was accompanied by gallstones and chronic cholecystitis findings, although the tumor was at an advanced-stage.

Since 1861, several studies have been reported on the association between chronic inflammation due to gallstones and gallbladder cancer (6). Recurrent or chronic inflammatory damages cause deoxyribonucleic acid (DNA) damage, and the release of cytokines and growth factors by triggering repetitive tissue proliferation interventions during repair, resulting in a predisposition to oncogenic transformation of the cells. Chronic inflammation may also be resulted from the formation of calcium deposits in the gallbladder wall. In some cases where the excessive accumulation of calcium gallbladder becomes fragile, the gallbladder is referred to as a porcelain gallbladder. In $12-60 \%$ of gallbladder cancer cases, the relationship with porcelain gallbladder has been reported in some studies. It has also been reported that punctual calcification is more likely to potentially be premalignant than transmural calcification (4).

The dysplasia of the biliary tract is considered to be a preinvasive lesion and is seen in 1-3.5\% of cholecystectomies. There is no finding during radiological and macroscopic examination, usually incidentally recognized at microscopy. It may 
be associated with invasive carcinoma, so it is recommended to take multiple samples when encountering dysplasia during microscopic evaluation of cholecystectomy. Dysplasia can be classified using a 2-grade (low, high) or 3-grade (Biliary intraepithelial neoplasia, BillN 1,2,3) classification system (8). Dysplasia was found in $5(0.5 \%)$ of our cases and dysplasia was low grade (BillN 1) in all. There was no high grade dysplasia.

Ultrasonography is preferred and gold-standard technique for diagnosing benign gallbladder diseases, an infiltrative malignancy may not be caught on ultrasonography (9). Although an expert radiologist may be able to recognize early lesions in the case of local wall thickening or small masses, abdominal ultrasound does not always detect any significant lesion in cases of early gallbladder cancer (10). Wall thickening (> $3 \mathrm{~mm}$ ) and improved vascularisation are ultrasonographic characteristics that also indicate probable cancer. Computed tomography (CT) aids to determine any lymph node, liver or distant organ reaching (4).

Gallbladder cancer may develop as a mass or polypoid growth, and can lead to the local thickening of the gallbladder wall (5). Gallbladder may show distension due to tumor, it may collapse due to neck of gallbladder or ductus cysticus obstruction (2).

The most common macroscopic finding during surgery and / or pathologic examination is thickening or inflammation in the gallbladder wall, which is nonspecific for malignancy, while less frequent findings include perforation, fistulation and necrosis and occasionally tumor mass (3). Therefore, even if there is no clinical suspicion, the examination and the histopathological evaluation of gallbladder specimens should always be conducted properly and carefully (5). The most common involvement is in the fundus and neck, about $20 \%$ of the lateral walls. Sampling should be done from these areas during macroscopic examination (11). The most common form is infiltrative and the second most common form is a papillary patern (12). In our case of primary gallbladder cancer, the tumor was located in the fundus region also and it showed ulceroinfiltrative development.

Over the last two decades, several specialists with surgical and histopathologic expertise have studied routinely or selectively histopathologic evaluation of cholecystectomy materials that were removed due to symptomatic cholelithiasis (7). In terms of cost, time and personnel savings, it is debated that whether or not all cholecystectomy materials should be sent for pathologic examination. However, when cancer is suspected on preoperative scanning or perioperative examination, histopathologic examination could be valuable (6). It is said that almost all incidental gallbladder carcinomas provide evidence in the examination performed by opening and sectioning in the operating room, because simple cholecystectomy is considered sufficient for initial stage (in situ and T1a) tumors (10). If there is a suspected gross lesion or if the patient has risk factors for gallbladder cancer, it is recommended to conduct intraoperative gross evaluation of resected specimen in order to detect if histological analysis is needed (13). Some studies have noted that pathologic evaluation may not be necessary if there is a correlation between imaging methods and intraoperative findings (macroscopic visual examination and mucosal examination in favor of any benign diagnosis by a surgeon). However, there is a need for further prospective and controlled studies to answer this important question (6). In fact, $15-40 \%$ of gallbladder carcinomas can not be detected during surgery (3). In the study by Shrestha et al., 9 of the 668 cholecystectomy materials had incidental carcinomas; wall thickening was found in 3 cases, distension in 2 cases, polyps in 1 case, and no obvious abnormality was observed in 3 cases intraoperatively (14). In the work by Koppatz et al., incidental gallbladder cancer was detected in 10 of the 2034 cholecystectomy materials, and in 10 cases in which macroscopically suspicious / abnormal signs were observed (local hardness in 1, wall thickening in 5 , acute cholecystitis in 1 , neoplasm in 3 ). No cancer was seen in the gallbladders without macroscopic abnormality (15). In their study involving 669 cases of gallbladder cancer, Roa et al. reported that $37 \%$ of the primary tumors were not grossly visible (16). In the prospective study by Kalita et al., the histopathologic results of 4115 gallbladder specimens were evaluated for a period of 3 years and carcinomas were diagnosed in 25 cases, of which 18 were reported as incidentally detected cases. The majority of the incidental cases were at a stage in which they were resectable (10 in T2, 7 in T1b and 1 in Tis) (1). In their study about whether there is a need for histopathological evaluation of the appendix, gallbladder and hemorrhoid material, Lohsiriwat et al. reported that there were no prior or intraoperative finding in the 24 incidental carcinomas detected histopathologically from 4317 cholecystectomy materials. They emphasized that routine histopathological analysis of the appendix and gallbladder is valuable, especially in empyema 
situations and in patients aged over 60 years, so that need for more treatment can be determined (17). Agarwal et al. reported that preoperative and intraoperative evaluation were effective in determining only $55 \%$ of all incidental conditions; in their study, 170 patients with gallbladder cancer, diagnosed at a center between 2000 and 2011, were treated as two groups. In the first group, patients were diagnosed early using histopathological evaluation. In the second group, the patients were diagnosed late with symptoms and without histopathological evaluation. In all the patients in the first group (100\%), the cancer was considered to be operable, in $69.9 \%$ of the patients, the tumor was resectable and median survival was 54 months. In the second group, these results were $49.4 \%, 7.8 \%$ and 10 months, respectively (10).

Stage determines the treatment of gallbladder cancer (12). Primary tumor (T) stage is main subgroup of the American Joint Cancer Staging Committee (AJCC) criteria and surgical method depends on it (4). Simple cholecystectomy is accepted effective management for Tis and T1a stage cases. Management of $\mathrm{T} 1 \mathrm{~b}$ is controversial between simple and radical cholecystectomy. Advanced stage tumors are managed with radical resection, and there is no role of adjuvant therapy (12).

Although the incidental malignancies are diagnosed at an early stage, the prognosis of the patient depends on some individual features, including older age, involvement of gallbladder neck, involvement of ductus cysticus surgical margin, maximum tumor diameter greater than $3 \mathrm{~cm}$, poorly histological differentiation, invasion of muscle layer, perineural invasion and lymph node involvement (9). In the study of Roa et al., the degree of differentiation and infiltration level were reported to be the most reliable prognostic factors (16).

For patients with gallbladder cancer, the mean overall survival rate is 6 months and the 5 -year survival rate is $5 \%$. This is partly related to the unique structure of the gallbladder; there is no serosa in the gallbladder in the face of the liver, the perimuscular connective tissue is sustaining with the liver connective tissue, thus allowing hepatic involvement and metastasis (4). In the study of Tian et al., 69 patients with incidentally detected gallbladder cancer were found to have 5 -year survival rates of $95.5 \%, 93.8 \%, 69.2 \%$ and $44.4 \%$ for T1a, T1b, T2 and T3 stages, respectively (18).

In conclusion; gallbladder cancer is a rare, but aggressive cancer and may not always give specific clinical findings. The diagnosis at early stage affects treatment outcomes. We believe that as in the general approach applied in our country, all cholecystectomy materials should be evaluated for pathological evaluation to not miss a possible malignancy, and macroscopic and microscopic examinations should be performed carefully. Fundus, neck and lateral walls should be sampled, even if there is no macroscopically evident lesion.

Conflict of interest: Authors declare that there is no conflict of interest between the authors of the article.

Financial conflict of interest: Authors declare that they did not receive any financial support in this study.

Address correspondence to: Fahriye Kilinc, Necmettin Erbakan University Meram Faculty of Medicine, Medical Pathology Department, Meram, Konya, Turkey

e-mail: drfahriyek@gmail.com

\section{REFERENCES}

1. Kalita D, Pant L, Singh S, et al. Impact of routine histopathological examination of gall bladder specimens on early detection of malignancy - a study of 4,115 cholecystectomy specimens. Asian Pac J Cancer Prev 2013;14(5):3315-8.

2. Albores-Saavedra J, Scoazec JC, Wittekind C, et al. Carcinoma of the gallbladder and extrahepatic bile ducts. In: Hamilton SR, Aaltonen LA, eds. World health organization classification of tumours, pathology and genetics of tumours of the digestive system. Lyon: IARC Press, 2000:206-14.

3. Emmett $C D$, Barrett $P$, Gilliam $A D$, et al. Routine versus selective histological examination after cholecystectomy to exclude incidental gallbladder carcinoma. Ann R Coll Surg Engl 2015;97(7):526-9.

4. Hundal R, Shaffer EA. Gallbladder cancer: Epidemiology and outcome. Clin Epidemiol 2014 7;6:99-109.

5. Khoo JJ, Nurul AM. A clinicopathological study of nine cases of gallbladder carcinoma in 1122 cholecystectomies in Johor, Malaysia. Malays J Pathol 2008;30(1):21-6.

6. Basak F, Hasbahceci M, Canbak T, et al. Incidental findings during routine pathological evaluation of gallbladder specimens: Review of 1,747 elective laparoscopic cholecystectomy cases. Ann R Coll Surg Engl 2016;98(4):2803 .

7. Jayasundara JA, de Silva WM. Histological assessment of cholecystectomy specimens performed for symptomatic cholelithiasis: Routine or selective? Ann R Coll Surg Engl 2013;95(5):317-22.

8. Katabi N. Neoplasia of gallbladder and biliary epithelium. Arch Pathol Lab Med 2010;134(11):1621-7.

9. Gulwani HV, Gupta S, Kaur S. Incidental detection of carcinoma gall bladder in laparoscopic cholecystectomy specimens: A thirteen year study of 23 cases and literature review. Indian J Surg Oncol 2015;6(1):30-5.

10. Agarwal AK, Kalayarasan $R$, Singh $S$, et al. All cholecystectomy specimens must be sent for histopathology to detect inapparent gallbladder cancer. HPB (Oxford) 
2012;14(4):269-73.

11. Adsay NV, Klimstra DS. Benign and malignant tumors of the gallbladder and extrahepatic biliary tract. In: Odze RD, Goldblum JR, eds. Surgical pathology of the GI tract, liver, biliary tract, and pancreas. 2 nd ed. Philadelphia: Saunders 2009: 845-75.

12. Talreja V, Ali A, Khawaja R, et al. Surgically resected gall bladder: Is histopathology needed for all? Surg Res Pract 2016;2016:9319147.

13. Patel K, Dajani K, lype S, et al. Incidental non-benign gallbladder histopathology after cholecystectomy in an united kingdom population: Need for routine histological analysis? World J Gastrointest Surg 2016 27;8(10):685-692.

14. Shrestha $R$, Tiwari $M$, Ranabhat $S K$, et al. Incidental gallbladder carcinoma: Value of routine histological examination of cholecystectomy specimens. Nepal Med Coll J 2010;12(2):90-4.
15. Koppatz H, Nordin A, Scheinin T, et al. The risk of incidental gallbladder cancer is negligible in macroscopically normal cholecystectomy specimens. HPB (Oxford) 2017 13. pii: S1365-182X(17)31153-X.

16. Roa I, Araya JC, Villaseca M, et al. Gallbladder cancer in a high risk area: Morphological features and spread patterns. Hepatogastroenterology 1999;46(27):1540-6.

17. Lohsiriwat $V$, Vongjirad $A$, Lohsiriwat $D$. Value of routine histopathologic examination of three common surgical specimens: Appendix, gallbladder, and hemorrhoid. World $\mathrm{J}$ Surg 2009;33(10):2189-93.

18. Tian $\mathrm{YH}$, Ji X, Liu B, et al. Surgical treatment of incidental gallbladder cancer discovered during or following laparoscopic cholecystectomy. World J Surg 2015;39(3):746-52. 